\title{
INTERCONNECTION BETWEEN BORDER MARKETS AND THE DYNAMICS OF SETTLEMENTS IN BORDER AREAS
}

\author{
(C) Mahtab Jafari \\ University of Tehran, Iran \\ science-almanac@mail.ru
}

Today, economists speak of trade as an engine of development. Many experts in development planning consider the creation of border markets to be a good strategy for bridging gaps in border areas and overcoming the current economic crisis. The purpose of this study is to analyze the impact of temporary border markets on cross-border employment and entrepreneurship in rural areas in the 3 villages of Hava Mirabad, Floos and Sarkol in the city of Marivan. In terms of data collection the purpose of the study is considered to be multifunctional. The population studied was 5532 people. The research used statistical methods. About 250 subjects were selected. The questionnaires were distributed in proportion to the number of rural borders. The validity of the Alfa Cronbach test was 0.74 percent, and detailed individual interviews were conducted with 20 expert conclusions. For the analysis of the data, the two-sided Student's test, the chi-square test, and the Kruskal-Wallis criterion were used. The results show that temporary border markets can have a positive impact on rural areas of employment and the entrepreneurial border, as well as the villages close to the border, with great influence on the temporary border markets. According to the Student's two-sided criterion, the rural population incomes in the result of the smuggling activities liquidation in the region after the creation of border markets before the creation of the markets decreased.

Key words: temporary border markets, employment, entrepreneurship, border areas

\section{[Махтаб Джафари Взаимосвязь между пограничными рынками и динамикой поселений в пригра- ничных района]}

Сегодня экономисты говорят о торговле как о двигателе развития. Многие эксперты по планированию развития считают создание пограничных рынков хорошей стратегией устранения пробелов в приграничных районах и преодоления нынешнего экономического кризиса. Целью данного исследования является анализ влияния временных пограничных рынков на приграничную занятость и предпринимательство в сельских районах, в 3 деревнях Хава Мирабад, Флоус и Саркол находящихся в городе Мариван. Цель исследования является многофункциональной и с точки зрения сбора данных. Исследуемое население составило 5532 человек. Исследование использовало статистические методы. Было отобрано около 250 субъектов. Анкеты распространялись соразмерно количеству сельских границ. Действительность теста Альфа Кронбаха составляла 0,74 процента, а также были проведены подробные индивидуальные интервью с 20 выводами экспертов. Для анализа данных использовались двусторонний критерий Стьюдента, критерий хи-квадрат, и критерий Крускала-Уоллиса. Полученные результаты показывают, что временные пограничные рынки могут оказать положительное влияние на сельские районы занятости и предпринимательской границы, а также близлежащие к границе деревни с большим влиянием на временные пограничные рынки. Согласно двустороннему критерию Стьюдента, доходы сельского населения в результате ликвидации контрабандной деятельности в регионе после создания пограничных рынков до создания рынков снизились.

Ключевые слова: временные пограничные рынки, занятость, предпринимательство, пограничные области. 
Mahtab Jafari - M.A. in Political Geography, Department of political geography, Faculty of Geography, University of Tehran, Iran

Махтаб Джафрари - магистр в области политической географии, кафредра политической географрии, факультет географии. Тегеранский университет. Иран

Today, economists speak of trade as an engine for the development. The establishment of border markets as a good strategy to address gaps in border areas and border out of the current economic crisis has been welcomed by many development planners [16]. The distant past frontier areas due to the inability of potential component isolated and deprived areas were considered. Therefore, cities and villages in these areas is very limited and of development are low. But with the globalization of industry, trade, finance and changes in the international system, strategic thoughts turned to the beliefs of economic geography borders. The new agreement, the center has to revise its relationship with the surrounding [12]. Inability of potential natural and economic Some of these areas, especially in the areas of agriculture, industry, immigration, differences and imbalances in the region and the space between central and border states in the time allowed, which on the eradication of poverty, creation employment, population retention, preventing the discharge of trafficking in border areas and measures to trade in the border areas [1]. The most important structural feature of these areas, the lack of diversity in the context of economic and employment opportunities, especially for increasing rural manpower [6]. One of the measures necessary for the dynamic economy of border areas, development of border transactions in regulated and facilitated border markets that can trigger good to increase formal exchanges, prosperity comparative advantages and expand cooperation and developing markets, regional, price stability, orientation of business profits, increased employment and prosperity for the community is residing in border regions [7].

Labor and employment, especially entrepreneurs, the principles of individual and social life is important at all ages and human communities is important. Entrepreneurship for human life in this world will be transformed. Economists and pundits are convinced that entrepreneurs by offering new products and services can lead society towards progress and development [9]. Today, in all communities and foster entrepreneurship is more or less emphasized And points of view and different ways to improve it, provided that depending on the circumstances of each community can benefit from them [15] .In general, one of the factors in rural development, entrepreneurship because, the entrepreneur can create new employment opportunities and income at an effective role in improving the economy and living conditions of rural areas. For this reason, measure and trying to develop rural entrepreneurship and foster entrepreneurship in rural development process, by providing early, it is very important. One of the ways to create jobs for the rural frontier to the establishment of border markets interim know that in the past decade in various regions of many of them have been established, in the city of Marivan two marketplaces temporary borders in the name of the old and ten RA Artisans established have became. For this reason, this study seeks to answer the question whether the temporary border markets have optimal performance on employment, entrepreneurship and rural people's income have frontiersman? In this study, the independent variable and cross-border markets, temporary employment, entrepreneurship and income as well as dependent variables are taken into account. The hypothesis of the research is as follows: 
- The seems that markets have failed to optimal performance in cross-border temporary employment, entrepreneurship and rural people's income have frontiersman.

- The seems that the employment and income of border markets in villages closer to border villages from the border to have a greater impact.

Theoretical Framework. Border Market

Border Market is an enclosed area, Located in the vicinity of the zero point of the border and customs, Customs clearance formalities are allowed to do or places where the agreements concluded between the Islamic Republic of Iran and neighboring countries to be determined [8]. The market into two general categories distinguished: 1) border markets trade sanctions economic: the market based on the decision of the Cabinet; and 2) markets or security for the markets licensed establishment by Council Supreme National security issued generally on the Iranian border with Iraq and Afghanistan and the security situation at a given time and space to be created [16]. According to experts, can promote cross-border economic activity and economic development of border areas, improving living standards, reduce poverty, income distribution, build a relationship of friendship and accelerate cooperation between border areas have an essential role [4]. The exchange of the country in which Export of goods, there is a relative advantage to act on it and replace it into the commodity which seems less advantages. Therefore, the optimal allocation of production factors, both countries will enjoy the benefits of trade. Although the model is Critics. Including the consequences resulting from such exchange losses less developed countries can be noted. But it can not be ignored benefit of the trade for each country [5]. A total economy a key role in the development of border areas and promote economic development in border areas, improving living standards, reduce poverty, income distribution, build relationships and learn more elaborated further cooperation between border areas have [14]. The reality is that today, two border has led neighboring countries in border markets common boundary of the known methods of economic development in rural frontiersman is considered and could be a major change in production, employment, population stabilization frontier, increasing income and ultimately create sustainable development and regional cooperation led to the act [11]. The main reasons for the formation of border markets can be summarized in the following: 1) Social: border markets vacuum within the borders remove and drain the sidelines borders prevent this in turn can raise the coefficient comes 3 ) political: political variables such important variables affecting the life of the markets. While trade can also have an impact on political relations Some empirical studies show. There is a common language and social mores close proximity to each other because the residents of these areas and thus boost the business [3].

\section{Entrepreneurship}

Entrepreneurship word from the French word "Entreprendre" means to take or "committing" originated. The view of Schumpeter, the entrepreneur is an innovator and a leader. Therefore, personal enterprise that combines new product creation, or like a man who wants to risk to organize and improve the re-economic mechanism and social acceptance, or like a person who has the use of market opportunities, imbalance between supply and demand of between takes, or a person who has a business of his own [10]. In other words, entrepreneurship, the willingness to make calculated risks in terms of financial jobs and then, do whatever possible to create advantages and privileges [2]. Rural entrepreneurship and rural entrepreneurs have in principle no different from other entrepreneurs and entrepreneurship. In fact, rural entrepreneurs as some characteristics that entrepreneurs elsewhere, even for high risk activities and the rural environment, as well as lack of resources and weak man- 
agement in the rural environment, rural entrepreneurs have much power more risks than others. Rural entrepreneurship can be so defined: identify new opportunities, innovation and creativity in agriculture and non-agricultural, innovation and creativity in land use and the optimum use, varied and innovative sources of rural areas in order to improve sustainable rural [13].

Table 1. National studies in the field of research

\begin{tabular}{|c|c|c|}
\hline $\begin{array}{l}\text { the writer or } \\
\text { writers }\end{array}$ & the subject & Results \\
\hline $\begin{array}{l}\text { Hajir Shamsi } \\
\text { et al. }\end{array}$ & $\begin{array}{l}\text { Position evaluating security and } \\
\text { sustainable development of bor- } \\
\text { der markets in border towns, } \\
\text { Case Study: Sardasht city } \\
\text { (2016) }\end{array}$ & $\begin{array}{l}\text { The establishment of border markets and create jobs for } \\
\text { residents of the frontier partly has a large number of rural } \\
\text { migrants to the city to reduce the establishment of border } \\
\text { markets in Sardasht milestone in production, employment, } \\
\text { population stabilization frontier, increase income and sus- } \\
\text { tainable development is. }\end{array}$ \\
\hline $\begin{array}{l}\text { Abed } \\
\text { Ebrahimi } \\
\text { Mastakani }\end{array}$ & $\begin{array}{l}\text { Socio-economic impact as- } \\
\text { sessment and the development } \\
\text { of rural areas on the border } \\
\text { Markets (2015) }\end{array}$ & $\begin{array}{l}\text { Feedback to this effect within a radius of six kilometers and } \\
\text { its economic impact in rural areas of social and declined. }\end{array}$ \\
\hline $\begin{array}{l}\text { Behroz Mo- } \\
\text { hammadi } \\
\text { Yeganeh }\end{array}$ & $\begin{array}{l}\text { Mehran border market economic } \\
\text { impact assessment of the de- } \\
\text { velopment of rural areas (2011) }\end{array}$ & $\begin{array}{l}\text { The market has managed economic development of rural } \\
\text { areas around the lead, income and other development indi- } \\
\text { cators other than the two components (production status, } \\
\text { well-being) all the significance level of less than } 0.01 \text { per- } \\
\text { cent respectively, indicating a positive impression Feed- } \\
\text { back on these indicators Is. }\end{array}$ \\
\hline $\begin{array}{c}\text { Ali } \\
\text { Mahmoudi }\end{array}$ & $\begin{array}{c}\text { The effect of border markets in } \\
\text { Bushehr economy (2002) }\end{array}$ & $\begin{array}{l}\text { Cooperatives due to financing exports and border markets } \\
\text { outside the province And the mediating role of the nodes in } \\
\text { the border exchange, the dramatic impact of their activities } \\
\text { on the development of non-oil exports and the boom in } \\
\text { economic and trade area is less visible. }\end{array}$ \\
\hline Eftkhari et al. & $\begin{array}{l}\text { Economic impact assessment of } \\
\text { the repercussions of the } \\
\text { development of border markets } \\
\text { (2008) }\end{array}$ & $\begin{array}{l}\text { The results obtained in this study suggests that positive } \\
\text { economic effect on the market has been able to leave its } \\
\text { surrounding areas. }\end{array}$ \\
\hline $\begin{array}{l}\text { Razini, \& } \\
\text { Bastani }\end{array}$ & $\begin{array}{l}\text { The role and functioning of the } \\
\text { border markets on the economy } \\
\text { in Kermanshah (2002) }\end{array}$ & $\begin{array}{l}\text { Border markets directly create about } 3,500 \text { jobs in the bor- } \\
\text { der areas have. } \\
\text { The share of border markets of non-oil exports have in- } \\
\text { creased in recent years While in } 1375 \text {, about } 1 \text { percent of } \\
\text { the exports were done in by the markets, in } 1380 \text { this share } \\
\text { to about } 5 \text { percent. }\end{array}$ \\
\hline Cholaki & $\begin{array}{l}\text { Economic assessment and } \\
\text { evaluation of the benefits of } \\
\text { border markets on the villages } \\
\text { around the city the Plains (2012) }\end{array}$ & $\begin{array}{l}\text { Feedback on the economic effects of improving living con- } \\
\text { ditions, income and well-being of rural households was very } \\
\text { low. The main reason for the official non-market and non- } \\
\text { arrival of goods from its principles, mutual lack of markets } \\
\text { between Iran and Iraq and inequality Sudan were exchang- } \\
\text { es for the minority villagers cocoon scholars, especially co- } \\
\text { coon Artisans and urban share of much less for the majority } \\
\text { of rural workers can be cited. }\end{array}$ \\
\hline $\begin{array}{l}\text { Simin Arma- } \\
\text { ghan }\end{array}$ & $\begin{array}{l}\text { Economic impacts of rural de- } \\
\text { velopment in the town of Astara } \\
\text { border markets (2011) }\end{array}$ & $\begin{array}{l}\text { To achieve the goals of economic development, export } \\
\text { growth, boost production, employment, reduce production } \\
\text { costs and regional development and the establishment of }\end{array}$ \\
\hline
\end{tabular}




\begin{tabular}{|l|l|l|}
\hline & $\begin{array}{l}\text { border markets, may be a suitable solution taken into ac- } \\
\text { count, and in the booming economic sector effects be posi- } \\
\text { tive. }\end{array}$ \\
\hline
\end{tabular}

Source: Findings, 2017

Table 1.1. International studies in the field of research

\begin{tabular}{|c|c|c|}
\hline $\begin{array}{l}\text { the writer or } \\
\text { writers }\end{array}$ & the subject & Results \\
\hline Nicholson R. & & $\begin{array}{l}\text { According to the results, the integration of location on the } \\
\text { border, generate greater returns and collection of its share- } \\
\text { holder countries has been developed. Foreign companies } \\
\text { active in the border areas, mainly in developed countries } \\
\text { more. }\end{array}$ \\
\hline Gaffney N. & $\begin{array}{l}\text { Business participation of multi- } \\
\text { national enterprises (MNE) in } \\
\text { emerging markets frontier: the } \\
\text { distance Economics and } \\
\text { Knowledge (2016) }\end{array}$ & $\begin{array}{l}\text { A greater level of transfer of assets with respect to targeting } \\
\text { investments in countries that are economically or } \\
\text { knowledge of the remote may wish to consider increasing } \\
\text { the level of participation of their companies. }\end{array}$ \\
\hline Wilson N. & $\begin{array}{l}\text { Transmission in the United } \\
\text { States and Mexico border econ- } \\
\text { omy: a regional association of } \\
\text { economic competition (2014). }\end{array}$ & $\begin{array}{l}\text { Only with strong institutions in the border areas can be in- } \\
\text { tegrated into border communities remain strong And that it } \\
\text { can be used for transactions and economic activities. Wil- } \\
\text { son believed that legislation and planning for the border } \\
\text { need to support strong and sustained financial and efforts. }\end{array}$ \\
\hline Huw E. T. & $\begin{array}{l}\text { The distance from the border } \\
\text { and its impact on the economy } \\
\text { (2015) }\end{array}$ & $\begin{array}{l}\text { According to Edwards on the border issues that affect the } \\
\text { economic effects are as follows: 1) The value and volume } \\
\text { of bilateral trade; 2) marginal trade; 3) competition in the } \\
\text { market and compete Haza company; 4) regional integration } \\
\text { and its benefits and costs; 5) trade, innovation and technol- } \\
\text { ogy overflow; 6) integration and macroeconomic conver- } \\
\text { gence. }\end{array}$ \\
\hline Niebuhr A. & $\begin{array}{l}\text { The effect of integration in } \\
\text { border areas and economic } \\
\text { theory and empirical studies } \\
\qquad(2002)\end{array}$ & $\begin{array}{l}\text { If relations between the border areas between the two } \\
\text { countries together seamlessly and enable economic ties of } \\
\text { the day, the border regions in terms of economic progress } \\
\text { achieved, and also to his opinion, since the balance of spa- } \\
\text { tial integration under affects the cost of transport may facili- } \\
\text { tate international and cross-border movements of construc- } \\
\text { tive change. }\end{array}$ \\
\hline Friese $\mathrm{F}$. & $\begin{array}{l}\text { Lampedusa economic borders } \\
\text { and immigration fledgling indus- } \\
\text { try in Sicily and Tunisia (2012) }\end{array}$ & $\begin{array}{l}\text { According to multinational and local conflicts in the alloca- } \\
\text { tion of resources and the interaction between the formal } \\
\text { and informal economy, cross-border traffickers and the is- } \\
\text { land of Lampedusa, which is related to the national pay- } \\
\text { ment. }\end{array}$ \\
\hline FTSE Paper & $\begin{array}{c}\text { Border markets, access to the } \\
\text { next frontier (2013). }\end{array}$ & $\begin{array}{l}\text { Border markets increased legal transactions, extended } \\
\text { monitoring functions of the exchange, development of in- } \\
\text { frastructure, access to foreign capital and businesses are } \\
\text { thriving. }\end{array}$ \\
\hline Santoro & $\begin{array}{l}\text { Frontier markets recently estab- } \\
\text { lished (2014) }\end{array}$ & $\begin{array}{l}\text { In most countries, border markets as well as have a posi- } \\
\text { tive impact on the economic indicators are border areas in } \\
\text { place, would have been to prevent corruption. }\end{array}$ \\
\hline Xinhua Gu & $\begin{array}{l}\text { The impact of border markets in } \\
\text { tourism economics }(2016)\end{array}$ & $\begin{array}{l}\text { The findings suggest that different border markets with re- } \\
\text { gard to trade between the countries improve the economic } \\
\text { situation of the region as well as the development of tour- } \\
\text { ism. The border markets makes traveling tourists from dif- } \\
\text { ferent countries. }\end{array}$ \\
\hline
\end{tabular}




\section{Research methodology}

The purpose of this study and in terms of data collection is descriptive and analytical. The theoretical method for collecting information and documents in the field of survey based on interviews and questionnaires were used. The research for the role of border markets in employment and entrepreneurship in rural areas are frontier. The study population into rural households in villages KhawMirabad, zarivar and Sarkol in the city of Marivan, form. Given the extent of the area and the difficulty of accessing $30 \%$ of the country's three villages in each district where a total of six villages in the covers by lottery as villages were selected and questionnaires to classification and randomly in villages were distributed among households. In field studies, to collect the required data, to prepare a questionnaire and were interviewed between the villages concerned, the most important part of field studies. For this purpose, a questionnaire was designed which included household questionnaire. The questionnaire included questions were closed questions. In designing questions, the Likert scale was used. Content validity was confirmed by a group of university professors and validity of the test Cronbach's alpha was 0.74 percent. Household questionnaire was distributed based on the number of selected villages. Based on a formula of population, 250 samples were obtained, as well as with 20 subjects to complete the findings, in-depth individual interviews took place. To analyze the data, paired t test, chi-square test (to determine whether or not people respond to questions of this test is used) and Kruskal-Wallis test was used in the software spss.

Table 2. Sample villages and distributed questionnaires among them

\begin{tabular}{|c|c|c|c|c|}
\hline Rural district & $\begin{array}{c}\text { The name of } \\
\text { the village }\end{array}$ & $\begin{array}{c}\text { The number } \\
\text { of } \\
\text { households }\end{array}$ & $\begin{array}{c}\text { Total } \\
\text { population }\end{array}$ & The number of questionnaires \\
\hline \multirow{2}{*}{$\begin{array}{c}\text { Khaw } \\
\text { Mirabad }\end{array}$} & Anjiran & 111 & 455 & 18 \\
\cline { 2 - 5 } & Bashmaq & 11 & 47 & 4 \\
\cline { 2 - 5 } & Daravaran & 83 & 334 & 16 \\
\hline \multirow{7}{*}{ Zarivar } & Kani kabod & 6 & 24 & 2 \\
\cline { 2 - 5 } & Kanisanan & 171 & 660 & 31 \\
\cline { 2 - 5 } & Ney & 656 & 2560 & 25 \\
\hline Sarkol & Balek & 139 & 529 & 20 \\
\cline { 2 - 5 } & Darziyan & 112 & 451 & 21 \\
\cline { 2 - 5 } & Sharani & 113 & 472 & 250 \\
\hline Total & 9 & 1402 & 5532 & \\
\hline
\end{tabular}

Research Area

City of Marivan is located in Kurdistan province and 135 kilometers west from Sanandaj. The city is ended to Saqz and Iraq from the north, it's ended to Pave, ion the East and the West it's ended to Sanandaj and Iraq respectively. According to the latest divisions city of Marivan has 3 sections, 3 cities, 6 districts and 151 populated villages (Statistical Yearbook of Kurdistan). In November, the population of the city was 267,661 people. 211,163 of these 
are living in urban areas and 11,700 are living in rural areas. 13,612 of the population living in rural parts of the city are male and 13121 of them are women. (Culture village in Kurdistan).

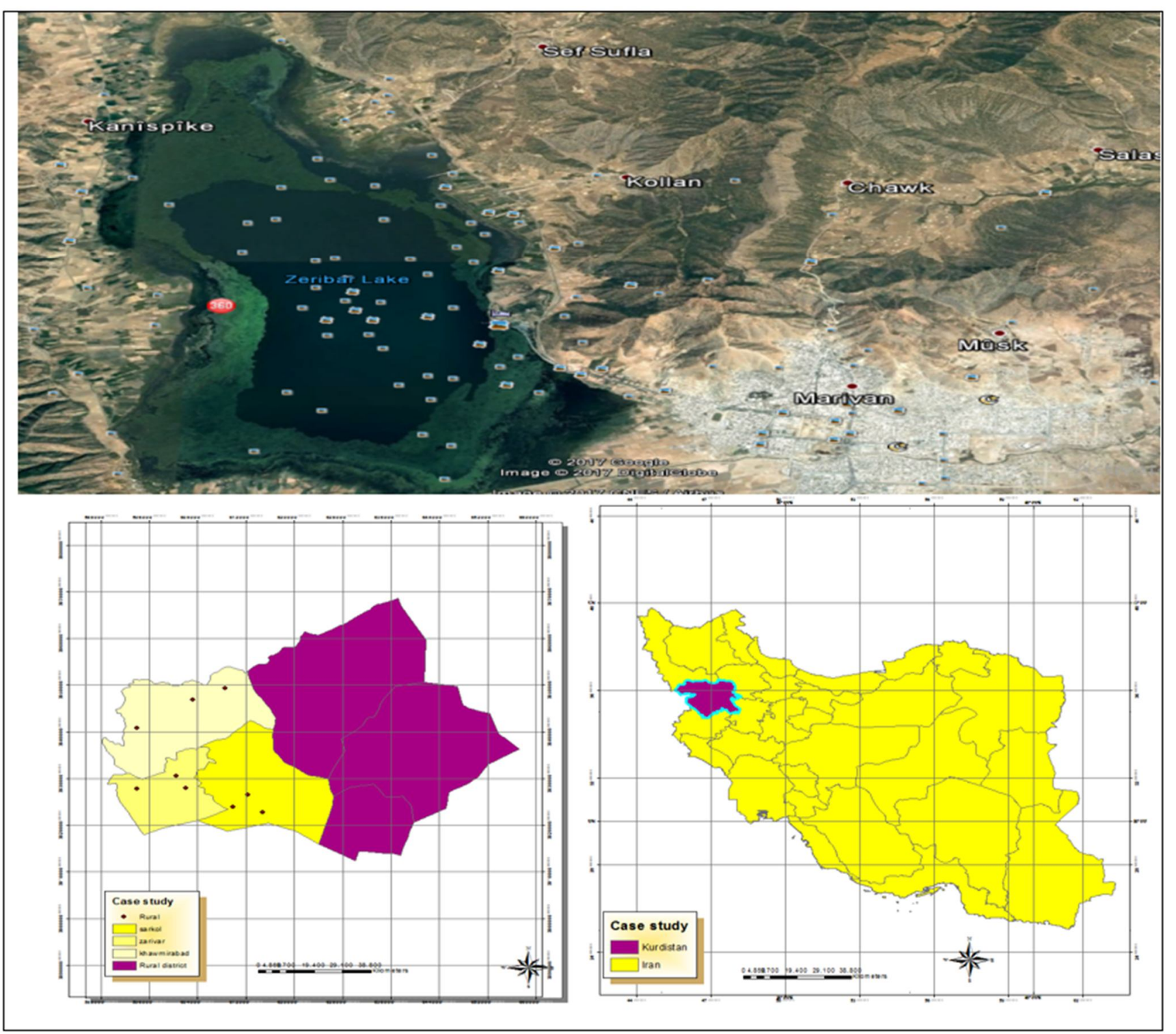

Research findings

Analysis of descriptive findings

Check the individual characteristics of the respondents indicate that all respondents were male, $15.3 \%$ of respondents aged $25-15$ years in terms of age, $28.1 \%$ of respondents aged $35-25$ years, $30.6 \%$ of respondents age $45-35$ years, $20.4 \%$ of respondents aged $55-45$ years and $5.5 \%$ in those aged over 55 years have been. In terms of education, 4.6 percent illiterate, $16.5 \%$ of subjects at the elementary level, 30.8 percent of people in the middle, 25.1 percent of high school and 22.9 percent of those in upper secondary level have been. More than $85 \%$ of their home's been at his residence.

Job status of respondents 
Job status of respondents in the overall level 2 main job and secondary jobs or other jobs have been evaluated. The main employment classification of the total sample size in terms of employment status of the respondents, $33 \%$ of agricultural jobs, $19.5 \%$ of public service jobs (shops, taxi driver between rural-urban), $7.6 \%$ of government employees, $24.2 \%$ of self-employed workers, 3.1 percent and 12.6 percent of the VA's other work. related industry and employment as well as employment due to lack of industry (large-scale or small) in the studied area, zero percent. $36.2 \%$ of people in employment lateral or side to Barry Cole, 29 percent work in the marketplace and $34.5 \%$ to other jobs (farmers, workers and services) are. In terms of job satisfaction, 9.8 percent of respondents too much, 16.4 percent of respondents most, 17.1 percent of respondents to some extent, 29.7 percent of respondents at least $27 \%$ of those with very little job to pay it are satisfied.

Table 3. The individual characteristics of respondents in rural areas, border areas

\begin{tabular}{|c|c|c|c|c|c|}
\hline \multicolumn{4}{|c|}{ Individual characteristics of respondents } & \multirow[b]{2}{*}{ average } & \multirow{2}{*}{$\begin{array}{l}\text { standard } \\
\text { deviation }\end{array}$} \\
\hline Index & Classification & frequency & percent & & \\
\hline \multirow{5}{*}{ Age } & $15-25$ & 15.3 & 125 & 7.12 & 4.057 \\
\hline & $25-35$ & 28.1 & 309 & 6.73 & 4.716 \\
\hline & $35-45$ & 30.6 & 490 & 7.59 & 4.859 \\
\hline & $45-55$ & 20.4 & 340 & 7.71 & 4.452 \\
\hline & $55>$ & 5.5 & 74 & 6.88 & 4.636 \\
\hline \multirow{5}{*}{$\begin{array}{l}\text { Level of } \\
\text { Eduction }\end{array}$} & illiterate & 4.6 & 62 & 5.36 & 4.245 \\
\hline & Primary & 16.5 & 141 & 7.48 & 4.388 \\
\hline & Guidance & 30.8 & 332 & 7.32 & 4.549 \\
\hline & High school & 25.1 & 416 & 7.38 & 4.621 \\
\hline & High school graduate or higher & 22.9 & 387 & 7.39 & 4.872 \\
\hline \multirow{6}{*}{ Main job } & Farmer & 33 & 441 & 7.98 & 4.632 \\
\hline & Public services & 19.5 & 288 & 7.14 & 4.447 \\
\hline & government's employee & 7.6 & 83 & 6.34 & 4.230 \\
\hline & Working & 24.2 & 297 & 6.93 & 4.955 \\
\hline & Dehyaran & 3.1 & 60 & 6.33 & 4.485 \\
\hline & Other & 12.6 & 169 & 6.76 & 4.568 \\
\hline \multirow{3}{*}{$\begin{array}{l}\text { Second } \\
\text { job }\end{array}$} & coolie & 36.2 & 485 & 7.35 & 4.780 \\
\hline & Working in the marketplace & 29 & 388 & 6.38 & 4.232 \\
\hline & Other & 34.5 & 461 & 8.05 & 4.755 \\
\hline \multirow{5}{*}{$\begin{array}{l}\text { Job Satis- } \\
\text { faction }\end{array}$} & too much & 9.8 & 131 & 7.54 & 4.693 \\
\hline & alot & 16.4 & 219 & 7.77 & 4.748 \\
\hline & So much for & 22.1 & 296 & 6.97 & 4.826 \\
\hline & little & 29.7 & 398 & 7.15 & 4.078 \\
\hline & very little & 22 & 294 & 6.36 & 4.652 \\
\hline
\end{tabular}


The establishment of border markets have different effects on the lives of rural areas frontiersman. Especially in the field of employment in these areas has caused a lot of changes. Research on the effects of border markets in variables studied.

Table 4. Answer villagers to influence variables border markets

\begin{tabular}{|c|c|c|c|c|c|c|c|c|c|}
\hline \multicolumn{2}{|c|}{ Index } & $\begin{array}{l}\text { too } \\
\text { much }\end{array}$ & alot & mediocre & low & seldom & $\begin{array}{l}\text { Aver- } \\
\text { age }\end{array}$ & $\begin{array}{c}\text { Chi- } \\
\text { square }\end{array}$ & Sig \\
\hline \multirow{2}{*}{$\begin{array}{l}\text { Tend to } \\
\text { migrate } \\
\text { due to } \\
\text { employ- } \\
\text { ploy- } \\
\text { ment }\end{array}$} & $\begin{array}{c}\text { fre- } \\
\text { quency }\end{array}$ & 61 & 97 & 86 & 71 & 45 & \multirow[t]{2}{*}{3.16} & \multirow[t]{2}{*}{23.222} & \multirow[t]{2}{*}{000} \\
\hline & $\begin{array}{l}\text { Per- } \\
\text { cent }\end{array}$ & 16.9 & 26.9 & 23.9 & 19.7 & 12.5 & & & \\
\hline \multirow{2}{*}{$\begin{array}{l}\text { A sense } \\
\text { of job } \\
\text { security } \\
\text { in border } \\
\text { markets }\end{array}$} & $\begin{array}{c}\text { fre- } \\
\text { quency }\end{array}$ & 14 & 28 & 76 & 132 & 110 & \multirow[t]{2}{*}{2.18} & \multirow[t]{2}{*}{143.889} & \multirow[t]{2}{*}{.000} \\
\hline & $\begin{array}{l}\text { Per- } \\
\text { cent }\end{array}$ & 3.9 & 7.8 & 21.1 & 36.7 & 30.6 & & & \\
\hline \multirow{2}{*}{$\begin{array}{l}\text { Feed- } \\
\text { back for } \\
\text { each } \\
\text { person } \\
\text { the ben- } \\
\text { efit of } \\
\text { the rural }\end{array}$} & $\begin{array}{c}\text { fre- } \\
\text { quency }\end{array}$ & 14 & 54 & 72 & 125 & 95 & \multirow[t]{2}{*}{2.25} & \multirow[t]{2}{*}{97.583} & \multirow[t]{2}{*}{.000} \\
\hline & $\begin{array}{l}\text { Per- } \\
\text { cent }\end{array}$ & 3.9 & 15.0 & 20.0 & 34.7 & 26.4 & & & \\
\hline
\end{tabular}

Studies show that most respondents believe that border markets had a significant impact on creating jobs for them. According to the responses and interviews with villagers, The reason for this dramatic reduction in smuggling activities after the establishment of markets and the inability to create alternative employment for a wide range of markets. Chi-square test results and meaningful to the average 2.78 percent less than the average (3) is So people have to say, believe the opposite border markets The main condition is not to create jobs for them. A resident of the village of figs says: "For several years, is working at the border or rather low and closed. Temporarily closed the border areas and established markets. That everyone has a book border could use markets. In some cases once a month is not my turn 
to go to the market and import goods. If the first day borders did not exist was much better because at least we went looking for a better job".

Table 5. Answers villagers to the impact of border markets in employment and entrepreneurship

\begin{tabular}{|c|c|c|c|c|c|c|c|c|c|}
\hline \multicolumn{2}{|c|}{ Index } & \multirow{2}{*}{$\begin{array}{c}\begin{array}{c}\text { too } \\
\text { much }\end{array} \\
71\end{array}$} & \multirow{2}{*}{$\frac{\text { alot }}{105}$} & \multirow{2}{*}{$\begin{array}{c}\text { mediocre } \\
91\end{array}$} & \multirow{2}{*}{$\frac{\text { low }}{58}$} & \multirow{2}{*}{$\begin{array}{c}\text { seldom } \\
35\end{array}$} & \multirow{3}{*}{$\begin{array}{l}\begin{array}{c}\text { Aver- } \\
\text { age }\end{array} \\
2.78\end{array}$} & \multirow{3}{*}{$\begin{array}{c}\begin{array}{c}\text { Chi- } \\
\text { square }\end{array} \\
21.056\end{array}$} & \multirow{3}{*}{$\begin{array}{l}\text { Sig } \\
.000\end{array}$} \\
\hline \multirow[t]{2}{*}{ Employed } & $\begin{array}{c}\text { fre- } \\
\text { quency }\end{array}$ & & & & & & & & \\
\hline & $\begin{array}{l}\text { Per- } \\
\text { cent }\end{array}$ & 19.7 & 29.2 & 25.3 & 16.1 & 9.7 & & & \\
\hline \multirow{2}{*}{$\begin{array}{l}\text { Entrepre- } \\
\text { neurial } \\
\text { opportuni- } \\
\text { ties }\end{array}$} & $\begin{array}{c}\text { fre- } \\
\text { quency }\end{array}$ & 6 & 39 & 67 & 132 & 116 & \multirow[t]{2}{*}{2.60} & \multirow[t]{2}{*}{43.056} & \multirow[t]{2}{*}{.000} \\
\hline & $\begin{array}{l}\text { Per- } \\
\text { cent }\end{array}$ & 1.7 & 10.8 & 18.6 & 36.7 & 32.2 & & & \\
\hline \multirow{2}{*}{$\begin{array}{l}\text { Non- } \\
\text { Aboriginal } \\
\text { employ- } \\
\text { ment }\end{array}$} & $\begin{array}{c}\text { fre- } \\
\text { quency }\end{array}$ & 98 & 109 & 59 & 63 & 31 & \multirow[t]{2}{*}{3.74} & \multirow[t]{2}{*}{117.444} & \multirow[t]{2}{*}{.000} \\
\hline & $\begin{array}{l}\text { Per- } \\
\text { cent }\end{array}$ & 27.2 & 30.3 & 16.4 & 17.5 & 8.6 & & & \\
\hline \multirow{2}{*}{$\begin{array}{l}\text { Service } \\
\text { jobs }\end{array}$} & $\begin{array}{c}\text { fre- } \\
\text { quency }\end{array}$ & 107 & 134 & 80 & 29 & 10 & \multirow[t]{2}{*}{2.37} & \multirow[t]{2}{*}{89.861} & \multirow[t]{2}{*}{.000} \\
\hline & $\begin{array}{l}\text { Per- } \\
\text { cent }\end{array}$ & 29.7 & 37.2 & 22.2 & 8.1 & 2.8 & & & \\
\hline \multirow{2}{*}{$\begin{array}{l}\text { Employ- } \\
\text { ment for } \\
\text { rural } \\
\text { women }\end{array}$} & $\begin{array}{c}\text { fre- } \\
\text { quency }\end{array}$ & 99 & 85 & 52 & 85 & 39 & \multirow[t]{2}{*}{1,19} & \multirow[t]{2}{*}{279.750} & \multirow[t]{2}{*}{.000} \\
\hline & $\begin{array}{l}\text { Per- } \\
\text { cent }\end{array}$ & 27.5 & 23.6 & 14.4 & 23.6 & 10.8 & & & \\
\hline
\end{tabular}

Given that only two temporary Markets (piran And daravaran) are active on the Cole, focus on these two markets. Many people in the city of Marivan to the markets and villages frontiersman come, because in some cases these markets to freely come and people in urban areas can also receive the goods they (the release of the border for Cole users in all days not happen. That's why a lot of people's everyday Marivan and remote villages go to the market and wait for hours. You may not get good most of the time). According to this index had significant chi-square test and Whereas the average 3.74\% and higher than average (3) is. The respondents in this case have agreed, in other words, they believe that after the es- 
tablishment of border markets for the employment of non-native areas in the border areas than in the past.

According to the consent of the respondents about the impact of border markets in their entrepreneurial opportunity, entrepreneurial opportunities for their border markets have had a great impact on. Chi-square test results and meaningful to the average 2.60 percent less than the average (3) is. So people are opposed to say that the main condition border markets in entrepreneurship is not for them. As a resident of the village of straw, said: "The official border Bashmaq much effect in improving our lives and not create jobs for villagers. Some people in the village daily to workers draining and time-consuming goods paid in the work, so the total is not the high count and should be of particular interest to traders and owners of the city is because we invest On temporary markets also did not count, because very little profit from it" (male, 48). According to the findings of the first research hypothesis is confirmed. In other words, a temporary border markets have failed to optimal performance on employment, entrepreneurship and rural people's income have frontiersman. Having regard to the views of respondents believe that service jobs were not significantly increase crossborder markets. Some of those questioned believed that. The impact of border markets in service jobs limited to loading in the markets is that very little income for individuals. The index had significant chi-square test and Whereas an average of 2.37 percent and below the average (3), so respondents are against this index. Since the work marketplaces dedicated to men's role and significant effect on employment of rural women did not, and even if the women who are heads of households cards border, to load and deliver the goods to a worker (Cole) Recruiters them. So, how satisfied respondents are very low 41.1 percent, 39.4 percent lower, partly for 17.5 percent, 1.1 percent and 0.8 percent, much was too much. The index had significant chi-square test and Whereas the average 1.91 percent less than the average (3) is. So respondents believe frontier markets had a significant impact on rural women's employment. According to research findings and responsive, after the establishment of border markets, rural-urban migration than in the past. Because of the removal of crossborder smuggling and laws and regulations, most people have lost their jobs and have been forced to migrate to cities. The response to this is that, totally opposed to 12.5 percent, against 19.7 percent, 23.9 percent intermediate, 26.9 percent were in favor and 16.9 percent completely agree. Therefore, most respondents believe for employment must migrate to the city. The index had significant chi-square test results and commented on average $3.16 \%$ and higher than average (3) is. So of respondents are willing to migrate for employment. A resident of the village of Bashmaq in this regard says: "living in the border villages without special features that are unique to this area is very difficult. We also have more incentive to stay. In the village with its lack of facilities for their children encounter the most problems for the people of this region have been"

Table 6. Answers rural income and reduce the impact of border markets in agriculture

\begin{tabular}{|c|c|c|c|c|c|c|c|c|c|}
\hline \multicolumn{2}{|c|}{ Index } & \multirow{2}{*}{$\begin{array}{c}\begin{array}{c}\text { too } \\
\text { much }\end{array} \\
2\end{array}$} & \multirow{2}{*}{$\frac{\text { alot }}{19}$} & \multirow{2}{*}{$\begin{array}{c}\text { mediocre } \\
61\end{array}$} & \multirow{2}{*}{$\frac{\text { low }}{142}$} & \multirow{2}{*}{$\frac{\text { seldom }}{136}$} & \multirow{3}{*}{$\begin{array}{c}\text { Average } \\
1.91\end{array}$} & \multirow{3}{*}{$\begin{array}{c}\begin{array}{c}\text { Chi- } \\
\text { square }\end{array} \\
233.694\end{array}$} & \multirow{3}{*}{$\begin{array}{l}\text { Sig } \\
000\end{array}$} \\
\hline \multirow[t]{2}{*}{$\begin{array}{c}\text { Income } \\
\text { level }\end{array}$} & $\begin{array}{c}\text { fre- } \\
\text { quency }\end{array}$ & & & & & & & & \\
\hline & $\begin{array}{l}\text { Per- } \\
\text { cent }\end{array}$ & 0.6 & 5.3 & 16.9 & 39.4 & 37.8 & & & \\
\hline $\begin{array}{l}\text { Reduced } \\
\text { agricultur- }\end{array}$ & $\begin{array}{c}\text { fre- } \\
\text { quency }\end{array}$ & 27 & 56 & 93 & 99 & 85 & 3.44 & 50.278 & .000 \\
\hline
\end{tabular}




\begin{tabular}{|l|l|l|l|l|l|l|l|l|}
\hline $\begin{array}{c}\text { al activi- } \\
\text { ties }\end{array}$ & $\begin{array}{c}\text { Per- } \\
\text { cent }\end{array}$ & 7.5 & 15.6 & 25.8 & 27.5 & 23.6 & & \\
\hline
\end{tabular}

In terms of job security, respondents believed that the job of border markets with a sense of job security is completely opposed to 30.6 percent, against 36.7 percent, 21.1 percent intermediate, $7.8 \%$ in favor and 30.9 percent completely agree. The index had significant chi-square test and Whereas an average of 2.18 percent and below the average (3), so respondents in this case are opposed. So people in the border areas of employment in border markets do not have a sense of job security. Studies show that the income of the rural markets are not the same for each person, so that the consent of the respondents, 26.4 percent completely disagree, 34.7 percent opposed, 20 percent intermediate, 15 percent in favor and 3. 9 percent completely agree., and that as many goods on different days. As well as some rural people in a couple days to allow the withdrawal of the product from the marketplace and others on odd days. So there is no possibility of profit equal to every rural person. The index had significant chi-square test and Whereas the average 2.35 percent less than the average (3), so respondents are opposed to the measure. It is significant to point out that cross-border markets have been effective in decreasing agricultural activities or not, here completely opposed to 18.9 percent, against 30.6 percent, 25.6 percent intermediate, $17.2 \%$ agreed and 7.8 percent completely agree. As you considerably more respondents are opposed to it. This means that cross-border markets is not effective in decreasing agricultural activities. 39.4 percent against 16.9 percent intermediate, 5.3 percent and 0.6 percent agreed completely agree. As is clear from the responses temporary border markets could have a positive impact on employment and entrepreneurship rural people. In other words, markets could temporarily fill the vacuum of smuggling.

Table 7. Results of paired t test comparing the average income of border markets before and after the elimination of trafficking

\begin{tabular}{|c|c|c|c|c|c|c|c|c|}
\hline \multicolumn{3}{|c|}{ Average } & \multirow[t]{2}{*}{$\begin{array}{c}\text { Standard } \\
\text { error }\end{array}$} & \multicolumn{2}{|c|}{$\begin{array}{l}95 \% \text { Confidence } \\
\text { Interval of the Dif- } \\
\text { ference }\end{array}$} & \multirow[t]{2}{*}{ Index T } & \multirow[t]{2}{*}{$\mathrm{df}$} & \multirow[t]{2}{*}{ Sig } \\
\hline & & & & Low & upper & & & \\
\hline \multirow{3}{*}{ Income } & Before & 2.88 & \multirow[t]{3}{*}{.130} & \multirow[t]{3}{*}{-.985} & \multirow[t]{3}{*}{-.471} & \multirow[t]{3}{*}{-5.580} & \multirow[t]{3}{*}{249} & \multirow[t]{3}{*}{.000} \\
\hline & After & 3.60 & & & & & & \\
\hline & $\begin{array}{l}\text { Mean dif- } \\
\text { ference }\end{array}$ & 0.72 & & & & & & \\
\hline
\end{tabular}

Source: Findings, 2017

Paired t-test showed that the income of frontier markets before and after the elimination of trafficking, The average have significantly different than 0.000 people and Income before elimination of trafficking has decreased. The reason for this is that more jobs for rural people has been linked to smuggling And after the establishment of these markets are not only not increased but decreased Income people. According to the results of the Kruskal-Wallis test, the relationship between the district and the impact of border markets in rural employment, as an average of the ratings with the Kruskal-Wallis test showed villagers in the village Khavv 
Mirabad impact of border markets in employment than other villages in the two districts are feeling more satisfied. Villagers in the next village because they work in the marketplace and Cole go for their second job is, In their view, the temporary border markets have been less effective in their jobs. As a result, the second hypothesis is confirmed. In other words, villages closer to border markets more effective than they are.

Table 8. Effect relationship between the district and border markets in rural employment

\begin{tabular}{|c|c|c|c|}
\hline & Rural district & Count & Average ratings \\
\hline \multirow{3}{*}{$\begin{array}{c}\text { The impact of border markets } \\
\text { in rural employment }\end{array}$} & Khaw and Mirabad & 38 & 138.67 \\
\cline { 2 - 4 } & & & 123.71 \\
\cline { 2 - 4 } & Zarivar & 146 & 121.89 \\
\cline { 2 - 4 } & Sarkol & 250 & \\
\cline { 2 - 4 } & Total & 2 & \\
\cline { 2 - 4 } & Df & 0.004 & \\
\hline
\end{tabular}

\section{Discussion and conclusion}

Source: Findings, 2017

Feedback temporary borders were established with the aim of creating employment for the rural frontier. This study investigates the role of border markets temporary employment and entrepreneurship in rural areas in the frontier district of Khaw and Mirabad, flows and has Srkl in the city of Marivan. In this connection, questions were raised as to their findings were. According to the findings of research and interviews, border markets before the elimination of smuggling jobs, many in the study area, so that the jobs most people smuggling and imports and exports was illegal, which is remove most of the villagers have lost their jobs. Alternatives (temporary markets, cross-border card) seeks to eliminate smuggling as well as optimal performance could have on employment in rural areas. So within a short time a lot of people smuggling were engaged, unemployment, and falling incomes and unemployment as two major obstacle to improve life in the village more in the region found that its reflection can be seen in the increased migration and off border villages and population increase in Marivan see. If the closing of the border with positive development in the field of economic and social frontier is not accompanied no doubt cost an exorbitant with a slight achieved, although to some extent this view is acceptable as a positive step, border markets for trade official responsible for establishing the villagers as alternatives, but as we mentioned, these markets are not efficient. According to the responses responsive and Chi-square test, frontier markets have had a great impact on rural employment. More impact on employment of non-native marketplaces that after the establishment of markets has increased. The employment of women in rural markets have much impact because of the role of women in the marketplace and there is no place. Also, because most of the work in the marketplace for Barry Cole and women do not do it. As we saw in paired t test results, the income of the villagers before the establishment of border markets more after it is established. And because it is related to people smuggling. Because the villages in the district in less than frontier markets relative to other villages are temporary. Next villagers in villages because work in the marketplace and Cole go for their second job is, in their view, a temporary border markets have been less effective in their jobs. As a result, the second hypothesis is confirmed. In other words, villages 
closer to border markets more effective than they are. It should be noted that the official trade through border markets in rural areas, thoughtful and practical approach is desirable. But the current situation is marked in such a way that the established markets in the region are faced with many challenges; As the villagers said, The main benefit to the wealthy urban markets receive. The local villagers and the villagers in the field of cargo and Barry Cole used on low incomes.

In this context, we propose solutions:

1. Formalize the trade of goods through the establishment of border markets in which villagers active in providing goods and services to be priority;

2. Reform of the legal and customs regulations border markets with the purpose of formal and legal border trade and development:

3 . Focusing on the development of border areas based on natural resources such as water, soil, vegetation and Mines area using local knowledge and strengthening its human resources through vocational training and promotion;

4. Planning for the development of small and medium industries in the region, due to the abundance of youthful energy in rural areas;

5. Planning and applicable for development of tourism in the regions according to their tourism potentials in the field of ecotourism and tourism businesses that will create jobs for rural residents and will eventually increase their income.

\section{References}

1. Ahmdipur Z., Hafeznia M., Mohammadpur A. Economic and social impact reopen border (sample: the ransom in the border of Iran and Turkmenistan) // Human geography studies. No 60 (65), 18-1. 2008.

2. Ashomre C. Criteria for youth entrepreneurship education. Consortium for entrepreneurship education // Retrieved September. 26(6). 2008.

3. Asheri A. Socio-economic and security impact assessment of construction of border markets and its role in the development of border areas (Case Study border markets peers (Sheikh Saleh)) // Second National Conference on economic development strategies with a focus on regional planning. Islamic Azad University of Sanandaj. 2011.

4. Chandoevwit W., Yongyuth Chalamwong S.P. Thailland's Cross border economy. A Case Study of Sa Kaeoand ChiangRa // Thailand Development Resource Institute (TDRI), 15(3). 2004.

5. Cholaki Kh. Economic assessment examining the benefits border markets on a case study of border markets bananas city of Sardasht in West Azerbaijan province // Fourth National Student Conference of geography. 2012.

6. Hoseini S.A. Analysis of factors affecting income and rural employment in Gilan province // Journal of Spatial Economic and Rural Development. 3 (1). 2014.

7. Kamran H., Mohammadpur A., Jafari.F. Bazarchh functional analysis Bajgiran border // Journal of the Geographical Society of scientific research. 6 (19). 2009.

8. Kohneposhi S.H., Anabestani A. The relationship between distance from the border and income and employment in the smuggling of goods (Case Study: KhawMirabad- part of Marivan) // Urban and Regional Studies and Research. 4 (15). 2012. 
9. Kuratko D.F., Hadgetts R. M. Entrepreneurship Theory. Process and Practice. U.S.A. 2004.

10. Lordkipanidze M. Enhancing Entrepreneurship in Rural Tourism for Sustainable Regional Development // The case of Soderslatt region, Sweden, 196(17). 2002.

11. Mahmudi $A$. The effects of transactions through border markets on customs revenues // Business Research. 6 (32). 2004.

12. Pena S. Land use Planning on The US - Mexico Border: A Comparison of The legal framework // Journal of Borderlands Studies. 17(1). 2002.

13. Petrin T. Entrepreneurship as an Economic Force in Rural Development. Keynote Paper. 1994.

14. Qaderi Hojat M. Role of security and sustainable development of border markets in surrounding areas Case Study: South Khorasan border markets // Journal of Geopolitics. 6 (3). 2010.

15. Sobel R. S., King K. A. Does school choice increase the rate of youth entrepreneurship? // Economics of Education Review.No 27(4). 2008.

16. Tayeb Niya $H$. The role of social and economic development of border markets in rural areas (Case Study: Khaw and Mirabad rural city of Marivan) // Journal of Spatial Economic and Rural Development. 5 (1). 2015. 